\title{
Using An Effective Online Learning Media on Student's Outcome
}

\author{
Sirrul Bari \\ English Department, Social and Humanity Science Faculty, University of Ibrahimy \\ Email Correspondence : sirulbari1992@gmail.com
}

\section{A R T I C LE IN F O}

\section{Keywords:}

Online Learning Media

Student's Outcome

\section{Article History:}

Received : 13 December 2021

Accepted : 02 February 2022

Published : 14 February 2022

\begin{abstract}
A B S T R A C T
This study determines the effect of using online media on student outcomes. This research was conducted at the state Khamas Vocational High School 2020-2021. The research method used was a survey and pre-experiment design with one group pre-test post-test. A number of sample 19 students, were divided into two groups. The instrument used questionnaire and score of pre-test post-test in experimental design. Data analysis techniques using analysis of t-test, and R-square tests. From a value of t-test, it was a significant influence between online method on student learning outcomes obtained at-count value of 9,481 $>1,793$ There is an influence of online learning media $(\mathrm{X})$ on learning outcomes $(\mathrm{Y})$, And continued for the know-how of value significant online learning method on student learning outcomes can see from the coefficient of determination test (R2) which means that there is an effect of using online learning media $(\mathrm{X})$ on student learning outcomes of $83,2 \%$ while $16,2 \%$ of student learning outcomes are influenced by other variables not examined.
\end{abstract}




\section{Introduction}

Online learning is an open and distributed learning system using pedagogical tools (educational aids), which are made possible through the internet and network-based technology to facilitate the formation of learning and knowledge processes through meaningful actions and interactions. Online learning media can be interpreted as media that is equipped with a control device that can be operated by the user, so that the user can control and access what the user needs, for example downloading resources for Tenses material in English lessons (Arnesti \& Hamid, 2015).

During the COVID-19 pandemic, the learning media used by the teacher is certainly different from the learning media that was carried out before the Covid-19 outbreak. The teaching media is part of a teaching strategy, where the teaching media serves as a way to present, describe, provide examples and provide training to students to achieve certain goals. As was done at the Khamas Asembagus Vocational School, the teaching media that was applied during this pandemic was online media in accordance with the circular letter of the minister of education that teaching and learning activities must be carried out with online media to break the ropes of the spread of the coronavirus. That is the reason why learning technique is needed in Learning activities to help students (KurniaWijaya, 2016).

Learning outcomes are the appearance of a person's success in achieving goals with excellence and excellence. Achievements are the results of efforts that have been made. Learning achievement is related to the expectations (expectation) formed through learning in their environment. Learning outcomes are the appearance of a person's success in achieving goals with excellence and excellence. The primary use of the term "outcome" refers to expectations set for students, competencies, skills, and knowledge the students are expected to demonstrate as a result of learning. In this application, the term "outcomes" is used in two ways(Ysseldyke \& Thurlow, 2012)

Applications that are applied at Khamas Vocational High School Asembagus are the Google meet, zoom, and WhatsApp group applications where this application aims to convey all learning that will be delivered by the teacher to determine the success of learning delivered through this online media. This opinion states that learning outcomes are an interaction between ability / and knowledge, motivation, and assignments. Or it can be said that to achieve achievement requires the ability and encouragement to carry out tasks (Santoso, 2009).

Several studies have shown the positive effects of e-learning from the insights of learners or students.1 For instance; e-learning allows observing many flexible learning ways to go for classes with a much-reduced need for travel. Learners are allowed to get deeper insights into the information through activities that are carried out in the classroom through an interactive video facility. This allows learners to respond promptly to the activities. Novita Arnesi and Abdul Hamid K students of Medan State University in 2015 entitled "use of online and offline learning media and interpersonal communication on English learning outcomes". The result that learned using online learning media is higher than offline learning media.

\section{Methods}

This research was held in Khamas Vocational High School Asembagus Jl. Pasar Hewan Asembagus Kertosari at the second class, get consist from two class, are: TKJ and MM. The population is all students of class XI KHAMAS Vocational High

School Asembagus totaled 68 students the sample size of a population can use a variety of methods, one of which is to use the Slovin technique (Ferdinand, 2014). 
From the solving technique then the number of samples used is 19 samples from the entire population determined using the accidental sampling method. The technique of using coincidences is that anyone who meets a researcher by chance can be used as a sample if it is deemed that the person met is suitable as a data source (Sugiyono, 2018).

Research methods used are survey and pre-experiment design with one group pre-test posttest. Several sample 19 students, were divided into one group, each group experimental. The instrument used questionnaire and score of pre-test post-test in experimental design. Data analysis techniques using analysis of normality test, linearity test, halogen test, t-test, and R-square tests (Gunawan, 2015), (Sugiono, 2014).

\section{Result}

Test normality is used to know the normality of data and to find out the distribution of data. ${ }^{18}$ It is used to measure whether the data in the data in theexperimental class and control class are normally distributed or not. ${ }^{19}$ In this research, used the SPSS statistic program with the ShapiroWilk formulation. The interpretationof the test of normality can be concluded as follows:

1) To decide Sig. standard example, 0,05 .

2) To compare it with Sig. standard of the result.

3) If the value of Asymp. Sig. (2-tailed) is grate than the rate of 5\% Alpha (Asymp. Sig (2tailed) $>0,005$ ) it can be concluded that the data is derived from populations that are normally distributed.

If the value of Asymp. Sig (2-tailed) is smaller than the Alpha level of 5\% (Asymp.Sig. (2-tailed) $<0,005$ ) it can be concluded that the data is derived from the population distribution is not normal.

Table 1. Normality Test

\begin{tabular}{lcccccc}
\hline & \multicolumn{3}{c}{ Kolmogorov-Smirnova $^{\text {a }}$} & \multicolumn{3}{c}{ Shapiro-Wilk } \\
& Statistic & Df & Sig. & Statistic & Df & Sig. \\
Pretest & .244 & 19 & .004 & .907 & 19 & .065 \\
postets & .119 & 19 & $.200^{*}$ & .974 & 19 & .847 \\
\hline
\end{tabular}

From the SPSS output table above, it can be seen that the value of Sig. Post-test is $0.847>0.05$. So according to the basis for decision making in the normality test using the Shapiro-Wilk method above, it can be concluded that the data distribution is NORMAL.

The linearity test aims to determine whether the two variables have a significant linear relationship or not. A good correlation should have a linear relationship between the independent variable $(\mathrm{X})$ and the dependent variable $(\mathrm{Y})$.

Table 2. Linearity Test 1

\begin{tabular}{|c|c|c|c|c|c|c|c|}
\hline & & & $\begin{array}{c}\text { Sum of } \\
\text { Squares }\end{array}$ & $\mathrm{df}$ & $\begin{array}{c}\text { Mean } \\
\text { Square }\end{array}$ & $\mathrm{F}$ & Sig. \\
\hline $\begin{array}{c}\text { hasilbelaj } \\
\text { ar* }\end{array}$ & $\begin{array}{c}\text { Between } \\
\text { Groups }\end{array}$ & $\begin{array}{c}\text { (Combine } \\
\text { d) }\end{array}$ & 605.825 & 6 & 100.971 & 26.728 & .000 \\
\hline $\begin{array}{l}\text { mediaonli } \\
\text { ne }\end{array}$ & & $\begin{array}{l}\text { Linearity } \\
\text { Deviation }\end{array}$ & 547.595 & 1 & 547.595 & 144.952 & .000 \\
\hline
\end{tabular}




\begin{tabular}{cccccc}
\hline from & 58.229 & 5 & 11.646 & 3.083 & .051 \\
Linearity & & & & & \\
Within Groups & 45.333 & 12 & 3.778 & & \\
Total & 651.158 & 18 & & & \\
\hline
\end{tabular}

From the results of the SPSS output above, the Deviation from Linearity Sig value is obtained. That is, 0.051 is higher than 0.05 . So, it can be concluded that there is a significant linear relationship between theonline learning variable $(\mathrm{X})$ and the learning outcome variable $(\mathrm{Y})$.

Test of homogeneity is used to determine whether the sample takenfrom the population have the same variance or do not show any significant differences from each other. Interpretation of the result of the homogeneity test is by looking at the value of Sig. (2-tailed). The test of homogeneityused the SPSS statistic program. The hypotheses for the homogeneity test are: H0 = The variance of the data is homogeneous.

$\mathrm{Ha}=$ The variance of the data is not homogeneous.

The interpretation of homogeneity can be concluded as follows:

1. If the significance is less than 0,05 (Sig. $(2$-tailed) $<0,05$ ), the variantsdiffer significantly (not homogeneous).

2. If the significance is greater than 0,05 (Sig. (2-tailed)> 0,05), thevariants are significantly similar (homogeneous).

The homogeneity test is a test of the equal or not variances of two or more distributions. The researcher used the SPSS application to get the dataof homogeneity test.

Table 3. Test of Homogeneity of Variances Pre-test

\begin{tabular}{cccl}
\hline Levene & & & \\
Statistic & df1 & df2 & Sig. \\
7.385 & 3 & 9 & 008 \\
\hline
\end{tabular}

Table 4. Test of Homogeneity of Variances Post Test

\begin{tabular}{cccc}
\hline Levene & & & \\
Statistic & $\mathrm{df} 1$ & $\mathrm{df} 2$ & Sig. \\
2.235 & 1 & 17 & .153 \\
\hline
\end{tabular}

Based on the result of the pre-test and post-test experiment group the sig. of the pre-the-test group is $0.008>0,05$, which means the data is homogeneous the sign of post-test the experiment group the sig is $0.153>0,05$, it means the data is homogenous.

The t-test shows how far the independent variables influence individually in explaining the variation in the dependent variable. The purpose of the t-test is to test the regression coefficient individually. The $t$ table value obtained is compared withthe $t$ value, if $t<$ from the $t$ table, then Ho is rejected, which means "the independent variable not ectfect the dependent variable. Vice versa, if $t$ count $>t$ table, is accepted, which means that "There is an effect of the independent variable on a dependent variable. 
Table 5. T-Test

\begin{tabular}{|c|c|c|c|c|c|c|}
\hline \multicolumn{7}{|c|}{ Coefficients $^{a}$} \\
\hline & \multirow[b]{2}{*}{ Model } & \multicolumn{2}{|c|}{$\begin{array}{l}\text { Unstandardized } \\
\text { Coefficients }\end{array}$} & $\begin{array}{c}\text { Standardize } \\
\mathrm{d} \\
\text { Coefficients }\end{array}$ & & \\
\hline & & B & Std. Error & Beta & $\mathrm{T}$ & Sig. \\
\hline 1 & (Constant) & -.391 & 2.918 & & -.134 & .895 \\
\hline & $\begin{array}{l}\text { Online } \\
\text { media }\end{array}$ & .429 & .045 & .917 & 9.481 & .000 \\
\hline
\end{tabular}

a. Dependent Variable: Learning outcomes

Based on the results of the SPSS output above, it is known that the $t$-count value is 9,481 . Next is to find the $t$ table. The Value $0.05 ; 19$ in the $t$ table is 1,729 . Because the $t$-count value is $9,481>$ 1,729 , it can be concluded that $\mathrm{H}^{0}$ is rejected and $\mathrm{H}^{1}$ is accepted, which means that "There is an influence of online learning media $(\mathrm{X})$ on learning outcomes $(\mathrm{Y})$.

The coefficient of determination (R2) explains how much the role of the independent variable on the dependent variable, in multiple linear regression the correlation coefficient is the contribution/contribution of the independent variable to the variable R2 value ranges from 0 to 1 the closer to 1 the regression line equation is the better. And it is said to be not good if it gets closer to the value $0 .{ }^{20}$ Thecoefficient of determination (KD) can be calculated using the formula: KD = $\mathrm{R}^{\wedge} 2 \times 100 \%$.

Table 6. (R2) Summary

\begin{tabular}{ccccr}
\hline & & & Adjusted R & \multicolumn{1}{c}{ Std. Error of } \\
Model & $\mathrm{R}$ & R Square & Square & the Estimate \\
1 & $.917^{\mathrm{a}}$ & .841 & .832 & 1.155 \\
\hline
\end{tabular}

a. Predictors: (Constant), media Online

From the results of SPSS Output above, it is known that R Square is 0.832 . This value means that the effect of using online learning media $(\mathrm{X})$ on studentlearning outcomes is $83,2 \%$ while $16,2 \%$ of student learning outcomes are influenced by other variables not examined.

\section{Discussion}

Online learning methods during the current pandemic are very important to be applied in the world of education. In connection with the research conducted at Khamas Vocational High School Asembagus, especially in class XI. So, the research results are obtained, as follows:

1. During the Covid-19 pandemic, online learning plays an important role in the world of education. Therefore, there is an effect of online learning on student learning outcomes at XI class of Khamas Vocational High School Asembagus.

In the test of the t-test, the results showed that there was a significant influence between online media on student learning outcomes which was seen from the hypothesis testing tested in SPSS obtained a t-count value of $9.481>1.729$ so it can be concluded that H0 is 
rejected and $\mathrm{H} 1$ is accepted, which means that "There is an influence of online learning media $(\mathrm{X})$ on learning outcomes $(\mathrm{Y})$.

2. Continued to find out how big is the significance value of online media on student learning outcomes, seen from the coefficient of determination test (R2) which aims to find out how much influence the online method has on student learning outcomes as indicated by the $\mathrm{R}$ square value of 83,2 . So, the influence of online methods on student learning outcomes is high.

The online method plays an important role in the world of education seen from the coefficient of determination (R2) it's a value of $83,2 \%$. Because when using the online method students are freer to find the necessary book references, through searching on goggle. There, students have more views on the learning material presented by the teacher, not only fixated on the handbook.

To find out how big the significance value of the online method is on student learning outcomes, the t-test is $83,2 \%$. So, the big is the significance value of online media on student learning outcomes method is $83,2 \%$..

\section{Conclusion}

The conclusion is the answer to the formulation of the research problem which is compiled in the form of a proposition or statement that has been tested for truth. Based on the results of research and discussion in chapter 4 , the conclusion is that there is a significant influence between online learning methods on student learning outcomes.

1. From a value of the t-test it is there is a significant influence between online method on student learning outcomes which can be seen from the trials that have been tested in SPSS obtaining the at-count value of 9,481 >1,793 so it can be said that H0 is rejected and H1 accepted, which means that "There is an influence of online learning media $(\mathrm{X})$ on learning outcomes (Y).

2. And continued to the know-how of value significant online learning method on student learning outcomes can see from the coefficient of determination test (R2) which means that there is an effect of using online learning media $(\mathrm{X})$ on student learning outcomes of $83,2 \%$ while $16,2 \%$ of student learning outcomes are influenced by other variables not examined.

H1 is accepted, namely "there is an effect of online learning on student learning outcomes of SMK KHMAS Asembagus for the 2020/2021 academic year".

\section{References}

Arnesti, N., \& Hamid, A. (2015). Penggunaan media pembelajaran online-offline dan komunikasi interpersonal terhadap hasil belajar bahasa inggris. Jurnal Teknologi Informasi \& Komunikasi Dalam Pendidikan, 2(1).

Ferdinand, A. (2014). Metode Penelitian Manajemen: Pedoman Penelitian untuk Penulisan Skripsi Tesis dan Desrtasi Ilmu Manajemen.

Gunawan, M. A. (2015). Statistik Penelitian bidang pendidikan, psikologi dan sosial. Yogyakarta: Parama Publishing.

KurniaWijaya, A. (2016). The Effect Of Using Mind Mapping On The Writing Comprehension Ability of The Tenth Grade Students At Sma Tiga Maret Yogyakarta In The Academic Year Of 
Yogyakarta State University.

Santoso, E. (2009). Pengaruh pembelajaran online terhadap prestasi belajar kimia ditinjau dari kemampuan awal siswa (studi eksperimen pada siswa kelas X SMA Negeri 1 Purwantoro Wonogiri). UNS (Sebelas Maret University).

Sugiono, P. D. (2014). Metode penelitian pendidikan pendekatan kuantitatif.pdf. Metode Penelitian Pendidikan Pendekatan Kuantitatif, Kualitatif Dan R\&D.

Sugiyono. (2018). Prof. Dr. Sugiyono. 2018. Metode Penelitian Kuantitatif, Kualitatif, dan R\&D. Bandung: Alfabeta. Prof. Dr. Sugiyono. 2018. Metode Penelitian Kuantitatif, Kualitatif, Dan R\&D. Bandung: Alfabeta.

Ysseldyke, J. E., \& Thurlow, M. L. (2012). Educational outcomes for students with disabilities. Routledge. 